\title{
TEOLOGICZNA PEWNOŚĆ NORM ETYCZNYCH W ENCYKLICE „HUMANAE VITAE” ${ }^{1}$
}

\section{ZAGADNIENIE DO ROZWIĄZANIA}

Od czasu słynnego dekretu La me n tabili z 3.7.1907 r., nazwanego przez modernistów dekretem opłakanym, la m e $\mathrm{n}$ t a ble, oraz od encykliki $\mathrm{Pascendi}$ dominici gregis z $8.9 .1907 \mathrm{r}$. nie było rozporządzenia doktrynalnego Stolicy Apostolskiej, którego przyjęcie i uznanie napotkałoby na tyle oporów i trudności co encyklika $\mathrm{H} \mathrm{umanae}$ $\mathrm{vi}$ t a e. Żadne $\mathrm{z}$ nich nie ukazało się bowiem $\mathrm{w}$ atmosferze równie niesprzyjającej. Liczne rzesze katolików i niekatolików, a nawet i rządy niektórych państw oczekiwały złagodzenia stanowiska Kościoła, potępiającego sztuczne środki regulacji urodzin.

Zmiany stanowiska Kościoła w tej sprawie domagali się także niektórzy biskupi i teologowie. Za zmianą wypowiedziała się nawet większość papieskiej komisji ekspertów, ustanowionej w r. 1963 celem gruntownego przebadania tego zagadnienia i przygotowania papieskiego orzeczenia: konieczność zmiany stanowiska uzasadniała ona zaś nowa interpretacją prawa natury. Ta właśnie nowa interpretacja prawa natury sprawiła, że o dopuszczalności sztucznych sposobów regulacji urodzin zaczęto mówić nie tylko w salach wykładowych, ale przeniesiono ją do konfesjonałów i według niej urabiano sumienia katolickich małżonków już od r. 1963, czyli od chwili powołania wspomnianej wyżej komisji papieskiej: zmianę tradycyjnej nauki Kościoła uważano więc w tych kołach za przesądzoną, względnie za prawie pewną.

1 Niniejsza rozprawa jest poszerzeniem i pogłębieniem wykładu, wygłoszonego $\mathrm{w}$ dniu 23.I.1969 r. w Krakowie na sympozjum, poświęconym encyklice Humanae vitae. 
I tak monachijska kuria kard. Döpfnera już w r. 1966 wydała dla duszpasterzy instrukcję zalecającą dopuszczanie do sakramentów tych małżonków, którzy korzystają ze sztucznych środków regulacji urodzin 2 . Doszło do tego, że w Niemczech zachodnich powszechnie tylko dzieciobójstwo i - niekiedy - poronienie uważano za moralnie zakazane. Episkopat holenderski okazał jeszcze większe zdecydowanie, bo w r. 1966 zatwierdził do powszechnego użytku słynny $\mathrm{K}$ atechizm dla dorosłych, który poucza wiernych tylko o niedopuszczalności dzieciobójstwa i poronienia. To właśnie stanowisko $\mathrm{K}$ a t e $\mathrm{ch}$ i z $\mathrm{m} \mathrm{u} \mathrm{dl} \mathrm{a} \mathrm{do-}$ rosłych znalazło się wśród siedmiu błędów, o które zgorszeni katolicy holenderscy oskarżyli go u Stolicy Apostolskiej.

Klimat niesprzyjający ukazaniu się encykliki $\mathrm{Hum}$ a nae vitae stworzyli również ci, którzy głosili, że Kościół powinien nie zabierać głosu na ten temat, gdyż zagadnienia pożycia małżeńskiego i regulacji urodzin zależą ostatecznie tylko od własnego sumienia małżonków. Podobną tendencję zdradzali już prawdopodobnie redaktorzy rozdziału o rodzinie $w$ soborowym schemacie XIII, gdy proponowali nast. sformułowanie: tylko małżonkowie, i ique soli, są tu właściwymi sędziami. Aby zagrodzić drogę tej tendencji skreślono w ostatecznej redakcji konstytucji soborowej O Kościele w świecie współczesnym te ostro zacieśniające słowa i iqu e s oli , ale tendencja pozostała nadal żywa. Po soborze wycisnęła nawet wyraźne piętno na duszpasterstwie małżeńskim $\mathrm{w}$ niektórych krajach. Oto - np. w Belgii — przyjęto zasadę, by w konfesjonale powstrzymać się od orzekania o moralności konkretnych przypadków stosowania regulacji urodzin, a ocenę ich pozo-

2 Poufna instrukcja duszpasterska monachijskiej kurii dostała się przez niedyskrecję naprzód do katolickiej prasy angielskiej. Za nią ogłosił ja N e w Y ork Times 31.3.1966 r. oraz paryski $L$ e $M$ ond e $z$ dnia 1.4.1966 r. Oto jej brzmienie według Le M ond e, w tłumaczeniu: „Dla szczęśliwego i świętego trwania małżeństwa chrześcijańskiego podstawowe znaczenie ma to, by młodzi małżonkowie od poczatku z determinacją poddali się woli Bożej.

W obecnych okolicznościach, już po kilku zaledwie latach małżeństwa. moga się oni łatwo znaleźć w sytuacji tak krytycznej, że posiadanie jeszcze jednego więcej dziecka - przynajmniej do pewnego czasu - byłoby znakiem braku odpowiedzialności, podczas gdy jedność małżeńskiego stadła jest i pozostaje nədal o najwyższej wartości dla wewnętrznej trwałości ich małżeństwa oraz dla dojrzewania ich miłości.

Kiedy ci małżonkowie, którzy usiłują przeżywać swe małżeństwo zgodnie z ich wzajemną chrześcijańską odpowiedzialnością oraz $\mathrm{z}$ troską o dobro dziecka, są przekonani, że w tej krytycznej sytuacji nie mogą obcować seksualnie bez środków antykoncepcyjnych, nie mogą być oskarżeni o nadużycie małżeństwa.

Małżonkowie odpowiedzialni, którzy widzą konieczność stosowania środków antykoncepcyjnych, nie przez lekkomyślność ani też na stałe, ale raczej jako bolesne wyjście z sytuacji przymusowej, winni wiedzieć, że nie są przez to wykluczeni od eucharystycznej Komunii.

Winni sobie z całą pokorą uświadomić, że są dopiero na drodze do dojrzałości i mają obowiązek czynić wysiłki w tym celu, by odpowiedzieć na miłosne zaproszenie Boga do pełni miłości”. 
stawić sumieniu małżonków. Wasze sumienie - poczęto im mówić jest według soborowej konstytucji duszpasterskiej O Kościele w świecie współczesnym wyłącznym sędzią w tych sprawach; postępujcie według sumienia. W takim uzasadnieniu przypisano Soborowi myśl, której on nie tylko nie miał, ale przed którą chciał się zabezpieczyć.

Przytoczone wyżej fakty są jedynie wybranymi przykładami, a nie wyczerpującym obrazem prądów panujących w Kościele przed ukazaniem się encykliki. Podanych przykładów żadną miarą nie wolno uogólniać. Nie znaczą one bynajmniej, jakoby większość episkopatów katolickiego świata i większość teologów hołdowała poglądom nieprzychylnym przyszłej encyklice $\mathrm{Humanae}$ vita e. Historyczna rzeczywistość była wręcz odwrotna: większość episkopatów świata oraz większość teologów katolickich podtrzymywała bez przerwy tradycyjną naukę Kościoła. Należy tu wymienić episkopaty: włoski, hiszpański, portugalski, jugosłowiański, austriacki i polski, jeśli chodzi o samą Europę. Właściwa wymowa trzech wybranych przykładów jest dla niniejszego studium następująca: dzięki wyjątkowo wielkiemu ciężarowi gatunkowemu teologii $\mathrm{w}$ trzech wymienionych krajach dokonana $\mathrm{w}$ nich ocena stopnia pewności norm etycznych encykliki wywrzeć musiała wielki wpływ na ośroki teologicznie słabsze. A tej oceny nie podobna zrozumieć w pełni, dopóki się nie uwzględni faktu, że jej autorowie aż do chwili ukazania się encykliki zajmowali stanowisko przeciwne jej normom.

Rzeczywiście, na teologicznie słabszy teren polski, podobnie jak i na obszar Ameryki, wtargnęła ocena encykliki wypracowana przez teologiczny ośrodek niemiecki, a głównie przez Karola Rahnera oraz Bernarda Häringa. Warszawski miesięcznik W i ę ź, w numerze styczniowym z roku 1969 rozpowszechnił wśród inteligencji polskiej ocenę $\mathrm{K}$ a rola $\mathrm{R}$ a hn era, drukując jego artykuł: $\mathrm{Na}$ marginesie encykliki, ,H umanae vitae" ${ }^{3}$. Wprawdzie poglądy B. Häringa na ten temat nie są znane $u$ nas szerszemu ogółowi, zostaną jednak przedstawione niżej dlatego, że Häring $\mathrm{z}$ tych samych zasad wyprowadza wnioski częściowo bardziej bezkompromisowe niż Rahner.

Poglądy swe na stopień pewności norm $\mathrm{Hum}$ a na e vita e wypo-

3 Oryginalny tekst niemiecki ogłoszony zostal w Stimmen der Zeit, 9 (1968) 193-210. Ponieważ obecna rozprawa zwraca się do polskich czytelnißów, którzy poglądy K. Rahnera znają tylko poprzez tłumaczenie ogłoszone w Więzi, poglądy Rahnera będą podawane tylko w polskim tłumaczeniu, w którym są znane. Należy więc zawsze mieć na uwadze to metodologiczne zastrzeżenie: 0 ile tlumaczenie jest wierne.

4 Bergen-Enkheim 1968.

5 Trzeba przyznać, że biskupi zachodnioniemieccy dokonali trudnej sztuki: tak dołączyli dzisiaj do stanowiska papieża, że bez niesławy opuścili swe stanowisko wczorajsze. 
wiedział Häring $\mathrm{w}$ broszurze pt. $\mathrm{Kr}$ is e $\mathrm{um}, \mathrm{H} \mathrm{um}$ a na e vita e” ${ }^{4}$.

Obydwaj słynni teologowie przyjmują za punkt wyjścia dla własnej oceny encykliki stanowisko episkopatu niemieckiego, wyrażone w liście pasterskim, z którego Rahner przytacza w swym artykule obszerny wyjątek. Zakłada zaś e pisk opat $\mathrm{ni}$ e mi ecki ${ }^{5}$ bezsprzeczny fakt, że normy etyczne $\mathrm{Hum}$ a nae vitae nie są nieomylną definicją ex c a thedra, po czym stawia następujące równanie: To co nie jest definicją ex cathedra, jest prowizoryczne; jest tymczasowe; nie może uchodzić bezsprzecznie za nieodwołalne; nie wyklucza możliwości błę$d u{ }^{6}$ Wprawdzie tego rodzaju nauki „mogą mieć rozmaity stopień obowiązywalności" ", ale cechy wymienione w powyższym równaniu są im wszystkim wspólne. Do takich właśnie prowizorycznych nauk należy treść encykliki $\mathrm{Hu}$ ma na vita e łącznie $\mathrm{z}$ jej normami etycznymi.

Prowizoryczny, tylko doraźny, p r o hic et nu n c, charakter norm zawartych w Humanae vitae uzasadnia i uwypukla episkopat niemiecki argumentem $\mathrm{z}$ teorii poznania: „W życiu ludzkim przychodzi nam zawsze "wedle najlepszej wiedzy i sumienia" kierować się prawdami, które $z$ jednej strony uznaje się jako pozbawione absolutnej teoretycznej pewności, a które jednak „,tu i teraz”, jako nie dające się dotąd przezwyciężyć, należy respektować jako ważne normy myślenia i działania. Również i Kościół... musi... nawet narażając się na niebezpieczeństwo błędu w jakimś szczególe, udzielać nauk, które... odznaczać się będą pewną prowizorycznością, nie wykluczając nawet niebezpieczeństwa błędu" 8 .

K. R a h n er mocniej niż episkopat podkreślił rzeczywistą możliwość zmiany nauki zawartej $\mathrm{w}$ encyklice: nie tylko wielokrotnie powtarza, że „podlega zasadniczo możliwości zmiany" ", względnie przekształcenia ${ }^{10}$, nie tylko tę możliwość rozciąga na ulepszenie sformułowania nauki - np. jej uściślenie czy wyrażenie w stylu prostszym i jaśniejszym - ale także dopuszcza zmianę jej przedmiotowej treści. Pisze bowiem w wyjaśnieniach, że wprawdzie narzuca się domysł, że nauka encykliki jest prawdziwa, ale taki domysł „w jakimś określonym przypadku może w teorii i praktyce ustąpić miejsca lepszemu, sumiennie uformowanemu przekonaniu, że słuszny jest pogląd przeciwny" 11 encyklice. Rzeczowo możności porzucenia kiedyś przez Kościół norm etycznych encykliki dowodzą, zdaniem Rahnera, również historyczne przypadki

6 Więź, 12 (1969, nr 1) 39.

7 Tamże, 38.

8 Tamże, 39 .

9 Tamże, 41.

10 Tamże, 40.

11 Tamże, 41. 
„rewidowanych później doktrynalnych wypowiedzi papieży, jak np. Wigiliusza, Honoriusza czy też niektórych sformułowań w bulli Ex s u r g a Dom in e Leona $\mathrm{X}$ oraz pewnej ilości oświadczeń papieskich o moralnej dopuszczalności pobierania procentu" ${ }^{12}$; a „,najnowszych czasach nie brakowało również papieskich wypowiedzi nauczycielskich o wadze zbliżonej do omawianej encykliki, które nie tyiko teoretycznie podlegały możliwości zmiany, ale też po cichu lub jawnie i wyraźnie były rewidowane" ${ }^{13}$, np. wypowiedzi doktrynalne Grzegorza XVI i Piusa IX w sprawie liberalnego i demokratycznego ustroju oraz wypowiedzi w sprawach biblijnych, skierowane przeciwko modernistom. Historyczne przykłady zmian doktrynalnych w Kościele są dla K. Rahnera wskazówką, że liczenie się z taką przekształcalnością jest nie tylko dozwolone, ale ,że katolik ma prawo i obowiązek liczyć się ze zmiennością wypowiedzi Urzędu Nauczycielskiego Kościoła nie mających charakteru definiującego" 14.

Znamiennym rysem Rahnerowej oceny encykliki jest to, że nigdzie nie omawia wyraźnie obowiązku posłuszeństwa wobec jej nauki, natomiast do rzędu obowiązku moralnego podnosi liczenie się z realną możliwością jej zmiany. Duża część artykułu poświęcona jest omówieniu praktycznych następstw takiego liczenia się $\mathrm{z}$ możliwością zarzucenia jej nauki przez Kościól.

Również B e rnard Häring nawiązuje do listu biskupów niemieckich, gdy o encyklice pisze: „Należy traktować poważnie wypowiedź papieża. Ponieważ oczywiście nie jest ona $z$ swej natury wypowiedzią nieomylną, ale rozwiązaniem, które w obecnej sytuacji wydaje mu się możliwie najlepsze, odpowiedzią nie może być akt wiary, ale tylko gotowość do wewnętrznego posłuszeństwa, innere Gehor-

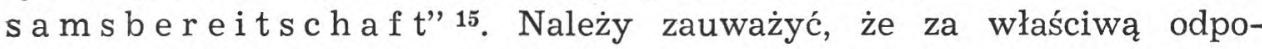
wiedź katolika na naukę encykliki nie podaje on wewnętrznego posłuszeństwa, ale tylko gotowość do takiego posłuszeństwa.

Praktyczne przejawy tej gotowości do posłuszeństwa oraz następstwa omylnego charakteru encykliki przedstawia Häring bardziej precyzyjnie i zwięźlej niż Rahner, dlatego warto się z nimi zapoznać: „Ci którzy mogą przyjąc encyklikę uczciwym sumieniem, winni to uczynić z wszystkimi konsekwencjami. Ci, którzy mają wątpliwości, czy mogą ją przyjąć, muszą ją studiować gruntownie i korzystać z innych informacji, by dojšć do jasnego rozeznania. Ci, którzy z uczciwym sumieniem nie mogą przyjąć nauki i wymagań encykliki „Humanae vitae”, powinni iść za swoim

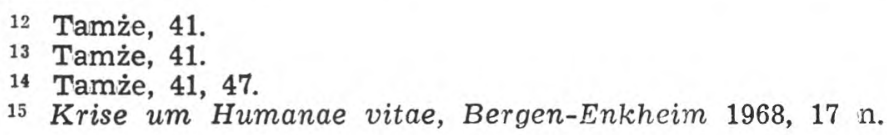


uczciwym sumieniem. Jeżeli więc małżonkowie dla dobrych racji i z dobrym sumieniem stosują środki do regulacji urodzin, które oni uważają za najbardziej przydatne - oczywiście z wykluczeniem poronienia nie muszą o tym wspominać na spowiedzi świętej. Kapłani powinni jasno pouczyć wiernych o nauce Papieża, nie przedstawiając jednak „Humanae vitae" jako ostatniego słowa Kościelnego Urzędu Nauczycielskiego" 16.

Stanowisko tego odłamu teologów wyraża się w ściślejszej terminologii metodologicznej w następujących twierdzeniach: a) Normy etyczne encykliki $\mathrm{Humanae}$ vitae są tylko teologicznie prawdopodobne, albowiem na mocy definicji tylko prawdopodobnym jest to twierdzenie, które dopuszcza możliwość prawdziwości twierdzenia przeciwnego.

b) Pewność etycznych norm encykliki jest tego samego stopnia co pewność argumentów, na których się opierają; pewność argumentów jest wystarczającym i całkowitym źródłem pewności norm. Tylko w tym założeniu jest możliwy wypadek „zdystansowania” się od norm encykliki przez tych, którzy rozporządzają bardziej przekonywującymi argumentami za nauką przeciwną.

c) Wszystkie orzeczenia doktrynalne Urzędu Nauczycielskiego, nie będące definicjami nieomylnymi mają jedną wspólną cechę, że są zasadniczo zmienne, czyli dopuszczają możliwość twierdzeń przeciwnych; zatem - w ściślejszej terminologii metodologicznej - mogą być uznane tylko za prawdopodobne. Nie wszystkie jednak obowiązują w tym samym stopniu.

Z prawdy nie może nigdy wynikać fałsz. Dlatego teoria, która prowadzi do podejrzanych wniosków, z konieczności musi sama wpaść w podejrzenie. A podejrzenie budzi to, co teologowie tego odłamu mówią o posłuszeństwie należnym encyklice. Bo Paweł VI domaga się w niej wyraźnie posłuszeństwa zewnętrznego i wewnętrznego i uzasadnia je opieką Ducha św.: „Obowiązek takiego posłuszeństwa - pisze - opiera się nie tyle na racjach podanych, ale raczej na świetle Ducha św., w które Pasterze Kościoła są w szczególny sposób wyposażeni dla wyjaśniania prawdy" 17. Tymczasem ci teologowie mówią jedynie o gotowości do posłuszeństwa względnie o szacunku dla encykliki, a pewność jej norm etycznych równają ze stopniem pewności argumentów uzasadniających je.

Rozprawa niniejsza zamierza właśnie dać odpowiedź na te pytania, podstawowe zarówno dla teoretycznej oceny encykliki jak i dla praktycznego ustosunkowania się wobec niej: a) Czy pewność norm etycz-

16 Tamże, 15.

17 Humanae vitae, nr 28. 
nych $\mathrm{Humanae}$ vita e może być mierzona wyłącznie i wystarczająco pewnością naukowych argumentów?

b) Czy ich pewność zamyka się w granicach prawdopodobieństwa?

c) Jeśli zaś wykracza ponad granice prawdopodobieństwa, jaka jest jej właściwa natura?

\section{PODSTAWY ROZWIAZZANIA}

Klucz do rozwiązania tych zagadnień nie leży na terenie naukowej etyki teologicznej, ale w eklezjologii, albowiem encyklika nie jest wyrazem profesorskiej działalności naukowo dydaktycznej, ale aktem Kościelnego Urzędu Nauczycielskiego: dlatego właśnie nie można jej norm oceniać wyłącznie w świetle wymagań stawianych rozprawom naukowym.

Podstawowym założeniem eklezjologicznym rozwiązania jest $\mathrm{n}$ i ez mienność na u i Chrystusowej, czyli objawienia. Jak przed dwoma tysiącami lat, tak dzisiaj i zawsze prawdą jest i będzie, że niebo i ziemia przeminą, ale słowa nauki Chrystusowej nie przeminą: oczywiście co do swego znaczenia i treści. Wiąże się z tym nierozerwalnie istnienie i niezmienność dogmatów pod względem ich treści: są one prawdziwe bezwzględnie, ponadczasowo; ich treść nie może być zaprzeczona; postęp w sformułowaniach dogmatycznych może dotyczyć jedynie szaty pojęciowo słownej, która jednak musi pozostać zawsze w obrębie tego samego znaczenia, in e ode m s e n su, in eadem sententia. Ponieważ rozwiązanie, przyjęte przez piszącego, zakłada treściową niezmienność dogmatów, nie spotka się oczywiście z. uznaniem tych teologów ,nowej linii”, którzy albo tę niezmienność odrzucają, albo nadają jej inny sens.

Dogmat, jak wiadomo, jest niczym innym jak nieomylnym wyjaśnieniem nauki objawionej dokonanym przez Kościół. A w $ł$ a ś c i wą p r z yczyną nieomylności Kościoła w wyjaśnianiu nauki objawionej nie jest ani głęboka wiedza, ani wszechstronne i wielowiekowe doświadczenie, ale tylko opieka Ducha św. Ta zaś nie ogranicza się tylko do tych aktów Urzędu Nauczycielskiego, w których Kościół - drogą uroczystą lub zwykłą - dokonuje nieomylnych definicji ex cathedra, ale rozciąga się na całe nauczanie zwyczajne, w k tórym Kościół wyjaśnia treśćnauki objawionej. Zacieśnianie opieki Ducha św. do samych tylko definicji ex cathedra jest sprzeczne z obietnicą Chrystusową. Albowiem Jezus przyrzekł Kościołowi swą opiekuńczą obecność na wszystkie dni aż do skończenia świata ${ }^{18}$; zapowiedział także, iż pośle Ducha św. 
po to, by „,był z wami na zawsze” 19 i nauczył Kościół wszelkiej prawdy. Mówiąc to miał bezsprzecznie na myśli nieprzerwaną obecność i pomoc Ducha św. w Kościele.

Tymczasem definicje ex cathedra, dokonane sposobem zwykłym czy uroczystym, nie są zjawiskiem codziennym w historii Kościoła, lecz przywiązane są do okoliczności wyjątkowo ważnych. Na dziewiętnaście wieków istnienia Kościoła przypada tylko 21 soborów powszechnych, a trzy z nich - mianowicie efeski z 431 r., lateraneński I z r. 1123 oraz lioński I z r. 1245 - nie dokonały żadnej definicji ex c a th e dra. Również liczbowo zwyczajne akty Urzędu Nauczycielskiego, nie będące nieomylnymi definicjami spraw wiary lub obyczajów, przeważają przytłaczająco nad ilością ostatecznych definicyj: mają się do siebie - w przybliżeniu - tak jak 6,5 do 1. Taki obraz otrzymujemy po przestudiowaniu znanego Enchiridion Symbolorum w wydaniu A. Schönmetzera ${ }^{20}$. Wszystkie przytoczone w nim dokumenty Urzędu Nauczycielskiego obejmują 3999 numerów marginesowych. Na soborowe definicje przypada 638 numerów; dorzucić musimy do tego 6 numerów ze względu na definicje nieomylne zawarte $w$ bullach Unam sanct a m Bonifacego VIII z r. 1302, B enedictus Deus Benedykta XII z r. 1336, Ineffabilis Deus Piusa IX z r. 1854.

Gdyby więc opieka Ducha św. była ograniczona do nieomylnych definicji, uroczysta obietnica Chrystusowa nie bylaby spełniona: Duch św. nie byłby nieprzerwanie obecny w Kościele nauczającym.

Dodać należy, że Kościół jest przekonany i uczy, że opieka Ducha św. rozciąga się na całą jego działalność nauczycielską, nie tylko uroczystą ale i zwykłą, czyli tą, którą przywykliśmy nazywać - nieściśle - działalnością omylną. Również Paweł VI, w przytoczonym wyżej tekście, przypisuje sobie wyraźnie opiekę Ducha św. przy ustalaniu etycznych norm encykliki $\mathrm{Humana}$ e vita e.

W tym świetle drugą podstawą rozwiązania jest ponadnaukowo pewna nauka katolicka, wyrażająca się w twierdzeniu: opieka Ducha św. rozciąga się na wszystkie akty Kościelnego Urzędu Nauczycielskiego. Chociaż jest to twierdzenie istotnie objawione, for m a l i t e r revel a t u m, i ponadnaukowo pewne, nie jest jednak dogmatem wiary. Przypuszczalnie z tego powodu nie biorą go pod uwagę przy ocenie encykliki ci, którzy chcą w niej widzieć jedynie tymczasowe rozwiązanie. Ale takie postępowanie jest niezgodne $z$ istotą teologii, która - jako intellectus fidei - winna obrać za podstawę całą treść katolickiej wiary, czyli całość objawienia, w zakresie którego dogmaty są tylko

$19 \mathrm{~J} 14,16$.

20 H. Denzinger - A. Schönmetzer, Enchiridion symbolorum, Ratisbonae 1965. 
małym wycinkiem. Takie postępowanie wskazuje także na to, że ci teologowie posługują się pojęciem Kościoła innym niż w tradycyjnej teologii oraz w nauce katolickiej: stanowisko wobec encykliki jest wyrazem ich swoistej eklezjologii.

Skoro opieka Ducha św. nad całą działalnością Urzędu Nauczycielskiego, tak zwyczajną jak uroczystą i nadzwyczajną, jest rzeczywistością, wynika stąd bezpośredni, konieczny czyli dedukcyjny, a niezwykle doniosły wniosek: aktów Urzędu $\mathrm{Nauczycielskiego} \mathrm{nie} \mathrm{mo-}$ żna wystarczająco wytłumaczyć przez czynniki wyłącznie historyczne, ludzkie, przyrodzone. Ten teologiczny wniosek, naukowo pewny, może być poddany w wątpliwość tylko wówczas, gdy się albo odrzuca opiekę Ducha św., albo jej poważnie nie bierze. Jest on - jako dedukcyjny - tak nierozerwalnie związany $\mathrm{z}$ istnieniem tej opieki, że jego odrzucenie lub osłabienie prowadzi nieuchronnie do jej odrzucenia lub osłabienia.

Jedną z cech orzeczeń Kościoła jest ich pewność. Powyższy wniosek dedukcyjny, zastosowany do pewności tych orzeczeń, przybiera brzmienie następujące: Pewności właściwej orzeczeniom Urzędu Nauczycielskiegonie można wystarczająco wytłumaczyć przez źródła pewności wyłącznie historyczne, zjawiskowe, ludzkie i przyrodzone. Ale oczywistość i pewność przesłanek jest jednym z podstawowych źródeł pewności: jest mianowicie podstawą pewności naukowej wniosków, wyprowadzonych z tych przesłanek. Naukowo pewne, powiada definicja, są te wnioski, które w sposób oczywisty wynikają z przesłanek uznanych za pewne. Wobec tego zastosowanie powyższego wniosku teologicznego do pewności orzeczeń Kościoła można równoważnie wyrazić w słowach: Pewności właściwej orzeczeniom Urzędu Nauczycielskiego nie można wystarczająco wytłumaczyć przez pewność naukową, opartą na oczywistości wynikania z przesłanek. Swą wystarczającą podstawę ma ona w opiece Ducha św., która nie tylko ochrania Kościół od błędu, ale i do-. pomaga $\mathrm{mu} \mathrm{w}$ odnalezieniu prawdy objawionej. Ponieważ wywodzi się od wszechmocnego i wszechwiedzącego Ducha św., jest $z$ konieczności większa i doskonalsza od pewności naukowej, czyli przyrodzonej. J e s t innymi słowy - pewnością ponadnaukową.

Taka jest trzecia podstawa rozwiązania, która również jest istotnie objawionym wnioskiem teologicznym, należącym do nauki katolickiej. W szczególności taką ponadnaukową pewność, wyższą od pewności racji dowodowych, przypisuje równoznacznie normom etycznym encykliki $\mathrm{Hum}$ a na e vita e Paweł VI, gdy uzasadnia obowią-- 
zek posłuszeństwa: „Obowiązek takiego posłuszeństwa opiera się nie tyle na racjach podanych, co raczej na świetle Ducha św." ${ }^{21 .}$

Podstawowy błąd metodyczny teologów niemieckich, stojących za listem biskupów Republiki Federalnej, K. Rahnera, B. Häringa i in., leży właśnie w tym, że przy ocenie pewności norm encykliki niedostatecznie biorą pod uwagę aktualny wpływ opieki Ducha św. na Biskupa Kościoła katolickiego przy powstawaniu encykliki. Jeśli się bowiem uwzględnia opiekę Ducha św., jako aktualną rzeczywistość nadprzyrodzoną, nie można sytuacji Pawła VI zrównać z położeniem rodziców, lekarzy i rządców, którzy muszą podejmować decyzje, mimo że nie rozporządzają całkowicie pewnymi kryteriami rozwiązania, nie można również pewności norm etycznych encykliki sprowadzić do prowizoryczności decyzji czysto ludzkich, powziętych $\mathrm{w}$ podobnych przymusowych okolicznościach. Rodzice, lekarze, rządcy państw nie mają wszak zagwarantowanej opieki Ducha św., która by ich chroniła przed postawieniem błędnej diagnozy lub przed wyborem niewłaściwego środka. Ograniczeni do własnych sił, wybierają to, co na podstawie rozumowych argumentów wydaje im się w danej chwili i w danej okoliczności - najodpowiedniejsze i najprawdopodobniejsze.

Tymczasem Kościół i Papież, jako jego głowa, oprócz przyrodzonych, ludzkich środków do poznania prawdy objawionej mają zapewnioną i nieprzerwaną pomoc wszechmocnego i wszechwiedzącego Ducha św., która uzdalnia go do bezbłędnego określenia objawionej prawdy nawet wówczas, gdy argumenty, jakimi rozporządza, nie dają całkowitej pewności j oczywistości. Argumenty naukowo teologiczne mogą nie posiadać bezwzględnej, ponadczasowej wartości; mogą być nawet logicznie niepoprawne i opierać się na błędnych przesłankach, ale określenie objawionej prawdy, do którego Kościół przy ich pomocy dochodzi, jest zawsze bezbłędne i posiada wartość ponadczasową: dzięki czujnej opiece i pomocy Ducha św., a nie dzięki logicznej mocy i wartości argumentów. Jest to tym bardziej prawdziwe, że do wyjaśnienia treści objawienia dochodzi Kościół nie tylko drogą rozumową, ale także drogą zmysłu wiary, s e n s u s fidei, dzięki któremu Kościół niejednokrotnie odnajdywał właściwą treść nauki objawionej na długo wcześniej niż naukowa teologia zdołała się do niej przebić poprzez teologiczne trudności ${ }^{22}$. Historia dogmatu Niepokalanego Poczęcia jest na to najbardziej znanym przykładem.

Ten sam dogmat jest również przykładem na to, że pewność orzeczeń Kościoła, określających treść nauki objawionej, jest zawsze większa od

$21 \mathrm{Nr} 28$.

22 Istnienie zmysłu wiary jest nauką Kościoła dzięki drugiemu soborowi watykańskiemu, który mówi o nim w konstytucji dogmatycznej o Kościele Lumen gentium, $\mathrm{nr} 12$. 
pewności argumentów, którymi się posługiwał. Mimo, że Niepokalane Poczęcie jest od przeszło stu lat dogmatyczną, nieomylnie pewną prawdą, ciągle jeszcze nie jest całkowicie pewne, gdzie i w jaki sposób zostało ono objawione przez Boga, a argumentacja przytoczona przez dogmatyczną bullę In effabilis Deus coraz mniej zadowala. Taki stan jest najbardziej zgodny zarówno z prawami logiki formalnej jak i z rzeczywistością nieprzerwanej opieki Ducha św. nad Kościołem nauczającym:

Z logiki formalnej wiemy, że prawda może wynikać zarówno z prawdy jak i z fałszu, mimo że z prawdy wynika zawsze tylko prawda. Wobec czego nieprzerwana opieka Ducha św. jako rzeczywistość nadprzyrodzona objawia swe istnienie nie tylko w tym, że orzeczeniom Urzędu Nauczycielskiego, określającym treść objawienia, gwarantuje zawsze pewność większą od pewności argumentów, ale także gotowa jest zapewnić tę pewność wtedy, gdyby przesłanki uzasadniające orzeczenie były fałszywe.

Do takich wniosków musi dojść każdy, kto poważnie bierze wiarę w nieprzerwaną opiekę Ducha św. nad Kościołem nauczającym. W tym świetle wolno więc powątpiewać, czy teologowie niemieccy, stojący za listem swych biskupów, biorą dostatecznie poważnie swą wiarę - którą napewno mają - w nieprzerwaną opiekę Ducha św. nad Kościołem. W tym świetle jest także jasne, że „pierworodny grzech” niedocenienia nieprzerwanej opieki Ducha św. zaistniał już przed ukazaniem się encykliki Humanae vitae; mianowicie wtedy, gdy zaczęto się domagać zmiany stanowiska wyrażonego przez Kościół w encyklice C a s ti c onnubii z r. 1931: zmiany norm etycznych, ustalonych przez nią, zaczęto przecież żądać w imię tego, że argumentacja Piusa XI po przeszło 30 latach straciła jakoby przekonywującą moc dowodową. W rzeczywistości zaś norma etyczna Casti connubii, identyczna w treści z normami $\mathrm{Hum}$ a n e vita e, posiada ponadnaukową pewność, większą od naukowej pewności argumentów dowodowych. Ponieważ nie wywodzi się właściwie z oczywistości argumentów dowodowych, ale z opieki Ducha św., nie może się zmniejszyć z tą chwilą, gdy argumenty dowodowe stracą na sile przekonywującej.

$\mathrm{Z}$ tym podstawowym błędem metodologiczno eklezjologicznym $\mathrm{z}$ w i ązany jest błąd pochodny: dla teologów omawianego ośrodka niemieckiego możliwość poprawienia argumentacji jest równoznaczna z możliwością zreformowania, czyli zmiany treści samejże normy etycznej. Tymczasem jest zasadnicza różnica pod względem pewności teologicznej między normami etycznymi $\mathrm{Humanae} \mathrm{vitae}$ a argumentacją uzasadniającą. Albowiem właściwym celem encykliki było tylko 
udzielenie odpowiedzi na pytanie: jakie normy etyczne obowiązują $\mathrm{w}$ świetle objawienia w sprawie regulacji urodzin? Tylko tego domagał się świat od Pawła VI; nie zależało mu zaś na rodzaju argumentacji. Dlatego wyjaśnieniem objawienia są w encyklice tylko normy etyczne; nie jest nim natomiast argumentacja encykliki, skoro nie jest jej właściwym przedmiotem i celem. Dlatego - z kolei - tylko na normy etyczne rozciąga się opieka Ducha św. i tylko one mają pewność ponadnaukową. Argumenty natomiast, o ile skądinąd nie są już ponadnaukowo pewne, posiadają jedynie któryś z stopni naukowej pewności teologicznej. Dlatego wreszcie z rzeczowej możliwości poprawienia argumentacji nie można nigdy wnioskować, że istnieje możność zmiany w treści nauki objawionejokreślonejprzez Kościól, a więc i treści norm etycznych encykliki.

Dotychczasowe wywody pozwalają odpowiedzieć na pierwsze z trzech pytań postawionych niniejszej rozprawie: Normy etyczne encykliki $\mathrm{Humanae}$ vitae mają pewność teologiczną ponadnaukową, wynikającą $\mathrm{z}$ opieki Ducha św. i większą od naukowej pewności argumentów, przytoczonych na ich poparcie; albowiem są istotnie zamierzonym przez Pawła VI aktem wyjaśnienia objawienia, dokonanym przy asystencji Ducha św.

\section{TEOLOGICZNA PEWNOSĆ NAUKOWA I PONADNAUKOWA}

Aby odpowiedzieć na dwa dalsze pytania postawione do rozwiązania oraz określić ściśle, pod jakim względem teologiczna pewność ponadnaukowa przewyższa naukową, należy najpjerw zdefiniować pojęcia pewności naukowej i ponadnaukowej.

Pewność pojęta psychologicznie, jest stanem umysłu: jest bowiem uznaniem prawdziwośoi sądu bez obawy błądzenia. Pojęta od strony teorii poznania, czyli e pistemologicznie, jest przymiotem sądu, który wyklucza możliwość błędu: to twierdzenie jest epistemologicznie pewne, które wyklucza możliwość błędu; a niepewne jest. to, które ją dopuszcza.

Jedną z istotnych cech każdej nauki jest oc zywis tość wy ni$\mathrm{kani} \mathrm{a}{ }^{23}$ : ma ona miejsce wówczas, gdy rozum widzi wynikanie dowodzonego twierdzenia $\mathrm{z}$ przesłanek uznanych za pewne. W teologii panuje pewność naukowa teologiczna, której właściwą podstawą jest oczywistość wynikania twierdzeń teologii z objawionych przesłanek, uznanych za pewne aktem wiary boskiej.

23 Por. I. Różycki, Metodologia teologii dogmatycznej, Kraków 1947, nr 6 nn. 
Pewnością ponadnaukową jest ta, która nie pochodzi $z$ naukowego dowodzenia i pochodzić od niego nie może. Posiadają ją np. najwyższe zasady bytu, które nie są przedmiotem żadnego dowodu, a są za to podstawą wszelkiego dowodzenia ${ }^{24}$. Ponadnaukowa pewność zasad jest więc pewnością wyższego rzędu niż naukowa pewność twierdzeń, które się na nich opierają.

Ponieważ właściwym źródłem pewności naukowej jest oczywistość wynikania, ma ona $z$ konieczności różne stopnie, tak jak są różne stopnie oczywistości. Obok oczywistości zenitowej i średniej, należy bowiem uwzględnić również oczywistość z mie r z chow ą. Największa, zenitowa oczywistość właściwa jest naukom doświadczalnym, pozostającym na pierwszym stopniu abstrakcji. Oczywistość średnia przysługuje naukom matematycznym, których dziedziną jest drugi stopień abstrakcji. Natomiast najmniejsza, zmierzchowa oczywistość jest przywiązana do trzeciego stopnia abstrakcji od materii, na którym poruszają się nauki filozoficzne, zwł. metafizyczna ontologia. Jak o zmroku tylko ludzie obdarzeni bystrym wzrokiem i tylko z pewnym trudem dostrzegają materialne przedmioty, podobnie tylko ludzie obdarzeni bystrym umysłem i tylko $z$ trudem dostrzegają rzeczywistość niematerialną na płaszczyźnie trzeciego stopnia abstrakcji 25 .

Wobec tego naukowa pewność, jaką można osiągnąć w filozofii, a zwłaszcza w metafizyce, jest o wiele słabsza niż pewność w naukach doświadczalnych i matematycznych. Nie tylko przyrodnik i matematyk są psychologicznie pewni tego, co twierdzą, ale ich twierdzenia udowodnione posiadają epistemologiczną pewność, bo wykluczają inną możliwość czyli możliwość błęd u. Nauka o przyrodzie wyklucza inne możliwości na drodze faktów, stwierdzonych doświadczalnie; matematyka zaś za pośrednictwem wewnętrznej sprzeczności. Jest faktem, że woda krzepnie tylko w temperaturze 0 Celsjusza; natomiast jest wewnętrznie sprzeczne, by trójkąt miał w geometrii Euklidesa więcej lub mniej niż 180 stopni w kątach wewnętrznych.

Epistemologiczną pewność twierdzeń nauk przyrodniczych i matematycznych można wyrazić w $\mathrm{zdaniach} \mathrm{modalnych:}$ as ertorycznych dla nauk przyrodniczych, a podyktycznych zaś w naukach matematycznych. J e st prawdą, że - dla przykładu - woda krzepnie w 0 Celsjusza; a jest bezwzględnie ko$\mathrm{nieczne}$, by w geometrii Euklidesowej suma kątów wewnętrznych trójkąta wynosiła 180 stopni.

24 Por. I. Różycki, Istnienie Boga, Kraków 1948, nr $102 \mathrm{nn}$.

25 Dz. cyt., nr 246-250; 304-306. 
Filozof, a zwłaszcza metafizyk, może posiadać pewność psychologiczną co do swych twierdzeń. Jeśli jednak zna możliwości i ograniczenia metody, jaką rozporządza oraz wyciąga wnioski $\mathrm{z}$ historii filozofii, może swym własnym twierdzeniom przyznać tylko epistemologiczne prawdopodobieństwo: oczywistość zwierzchowa, w której się obraca, sprawia bowiem, że możliwość błędu osiąga częstotliwość krótszą niż jedno naukowe życie ludzkie. Każde nowe pokolenie tworzy swą własną filozofię, i trudno w historii wskazać na wielkiego filozofa, który by nie zmienił przynajmniej niektórych swych twierdzeń. Całkowitą epistemologiczną pewność mają tylko te twierdzenia filozofii, które należą do wspólnej spuścizny, patrimonium perenne.

Oczywistość wynikania, będąca źródłem naukowej pewności teologicznej, jest również zmierzchowa, albowiem przedmiotem właściwym objawienia, które jest punktem wyjścia dla teologicznego poznania, jest Bóg i sprawy związane z Bogiem. A Bóg jest bezwzględnie najbardziej odległy od materii i abstrakcja, konieczna do tego, by o Nim rozprawiać, przewyższa znacznie największą abstrakcję metafizyczną. Gdyby więc teologia nie miała oparcia w czynnikach ponadnaukowych, tj. w żywej Tradycji oraz $\mathrm{w}$ nadprzyrodzonym zmyśle wiary, podlegałaby jeszcze większej zmienności niż systemy metafizyczne. Historia przemian protestantyzmu oraz teologii protestanckiej jest na to dowodem. Dzięlki ciągłej interwencji wspomnianych dwu ponadnaukowych czynników teologia katolicka nie podlega wprawdzie ani tak rozległym ani tak częstym przemianom jak protestancka, ale tam, gdzie działa o własnych siłach, czyli wyłącznie w oparciu o oczywistość wynikania $z$ przesłanek objawionych, posiada jedynie oczywistość zmierzchową, najsłabszą pewność psychologiczną oraz epistemologiczne prawdopodobieństwo twierdzeń, dopuszczające możliwość błędu o częstotliwości jednego naukowego życia.

Teologiczną pewność ponadnaukową posiada każde wyjaśnienie nauki objawionej dokonane przez Kościelny Urząd Nauczycielski. Ma ona dwa źródła: dals zy mest niezawodność objawienia Bożego, a. bliskim i właściwym jest nieprzerwana opieka Ducha św. Ona właśnie pozwala Kościołowi nauczającemu przezwyciężyć wszystkie skutki zmierzchowego poziomu oczywistości wynikania, do którego ograniczona jest nauka teologiczna. Dlatego akt uznania prawdziwości kościelnego wyjaśnienia objawienia musi pod względem psychologicznym posiadać nie tylko większą, ale także innego rodzaju pewność niż akt uznania twierdzenia teologicznie naukowo pewnego. Pod względem epistemologicznym zaś twierdzenia Kościoła, wyjaśniające treść objawienia, z tego samego powodu muszą 
wznosić się ponad prawdopodobieństwo, dopuszczające możliwość błędu na przestrzeni jednego pokolenia.

Wyłania się pytanie podstawowe dla niniejszej rozprawy: $\mathrm{jak} \mathrm{da}$ leko teologiczna pewność ponadnaukowa wykracza ponad poziom prawdopodobieństwa, z jakim spotykamy się na terenie nauk filozoficznych i teologicznych?

Katolicka eklezjologia odróżnia w nauce Kościoła dwie klasy zdań: orzeczenia nieomylnie pewne, in fallibiles, czyli definicje oraz orzeczenia, które nie są definicjami. Prawdziwość definicji nieomylnie pewnych uznana musi być aktem wiary boskiej; a pod względem epistemologicznym mają one czystą i całkowitą pewność objawienia Bożego, czyli wykluczają jakąkolwiek możliwość błędu. O każdym twierdzeniu nieomylnie zdefiniowanym należy wypowiedzieć sąd modalny: jest ono istotnie przez Boga objawione i nieomylnie, bezwzględnie pewne. Wyrażają one prawdę bezwzględną, veritatem absolutam, i dlatego nie zaistnieje nigdy taka chwila, w której by pod względem swej treści okazały się fałszywe i wymagały zmiany.

Obliczenia przeprowadzone wyżej na podstawie Enchiridion symbolorum wykazały, że nieomylne definicje stanowią zaledwie 13 procent doktrynalnych dekretów Kościoła; olbrzymia reszta, bo około 87 procent, należy do klasy drugiej, czyli do orzeczeń nie będących definicjami.

\section{PONADNAUKOWA PEWNOSĆ ORZECZEŃ KOSCIOEA, NIE BĘDĄCYCH DEFINICJAMI NIEOMYLNYMI}

Nie podlega najmniejszej wątpliwości, że normy etyczne $\mathrm{H} \mathrm{u}$ m a n a vita e nie są nieomylną definicją ex cathedra. Gdyby Paweł VI chciał tę sprawę ostatecznie nieodwołalnie i nieomylnie rozstrzygnąć, musiałby ten zamiar jednoznacznie wyrazić; bo tak nakazuje nie tylko przepis prawa kanonicznego, ale i natura wewnętrznej celowości tego nadzwyczajnego aktu nauczycielskiego. $\mathrm{Na}$ taki zamiar nie wskazują ani okoliczności ogłoszenia ani tekst encykliki.

Uznanie norm etycznych encykliki za prowizoryczne, podlegające rewizji, wyrosło z błędów, nieścisłości i nieporozumień związanych z przynależnością $\mathrm{Humanae} \mathrm{vita} \mathrm{e} \mathrm{do} \mathrm{drugiej} \mathrm{klasy} \mathrm{orzeczeń} \mathrm{Kościoła:}$

B łąd jest w tym, że drugą klasę orzeczeń uważa się za grupę jednorodną: ponieważ niektóre $z$ nich $z$ własnej natury, czyli $z$ swego właściwego przeznaczenia są tymczasowe, prawdopodobne i dopuszczają możliwość zmiany, o wszystkich - więc i o $\mathrm{Humanae}$ vitae twierdzi się, że są prowizoryczne, tylko prawdopodobne i dopuszczają 
możliwość zmiany. Jest to klasyczny błąd logiczny, polegający na nieuprawnionym wnioskowaniu z części o całości. W rzeczywistości zaś druga klasa orzeczeń Kościoła rozpada się na dwie różnorodne grupy: orzeczeń prowizorycznych i tylko prawdopodobnych oraz orzeczeń nieodwołalnych, wykluczających możliwość błędu i zmiany oraz epistemologicznie całknwicie pewnych. Są nieodwołalne, wykluczają możliwość zmiany i błędu oraz ponadnaukowo pewne te orzeczenia, w których Kościół dokonuje wyjaśnienia treści objawienia. Prowizoryczne, tylko prawdopodobne, dopuszczające możliwość zmiany są natomiast te wypowiedzi Urzędu Nauczycielskiego, w których Kościół nie ustala właściwej treści objawienia, ale ogranicza się do wskazania, jakie twierdzenia są dla niej niebezpieczne.

Nieścisłość, prowadząca do nieporumień i błędów, jest w obiegowej nazwie: orzeczenia omylnie pewne, fallibiles. Taka nazwa podsuwa myśl, że w tych orzeczeniach Kościół nie tylko może się omylić, ale rzeczywiście niekiedy się myli i zmuszony jest do zmiany swego stanowiska. Ci, którzy mówią o prowizoryczności norm etycznych Hum a n a vita e, liczą na taki wypadek. Po wtóre ta. nazwa jest niewystarczająca, bo przemilcza istotny przymiot tych wszystkich orzeczeń Kościoła, w których dokonuje się wyjaśnienie i ustalenie treści objawienia: w świetle nauki Kościoła są one wszystkie bezbłędne, inerrantes. Ich pełna nazwa winna zatem brzmieć: orzeczenia omylne ale bezbłędne, propositiones fallibiles sed inerrantes. W świetle tej terminologii klasa orzeczeń nie będących definicjami nieomylnymi dzieli się zatem na grupę orzeczeń zasadniczo omylnych ale faktycznie bezbłędnych oraz na grupę orzeczeń tymczasowych, tylko prawdopodobnych.

Terminologia ta wystarcza, by się nie zagubić w interpretacji działalności Urzędu Nauczycielskiego, ale nie wyraża wszystkiego, co objawienie i Kościół o niej mówi. Wystarcza zatem do tego, by dać odpowiedź na pytania, które zamierzamy rozwiązać. Aby jednak w ściślejszy i pełniejszy sposób oddać treść objawienia, zostanie przeprowadzona poniżej próba udoskonalenia tej przyjętej terminologii.

Podział orzeczeń Kościoła nie będących nieomylnymi definicjami na powyższe dwie grupy jest koniecznym następstwem Jego podwójnej misji w stosunku do skarbca wiary, depositum fidei: „Kościół jest stróżem i nauczycielem objawionego słowa" - uczy pierwszy sobór watykański ${ }^{26}$; nauka objawiona przez Boga — powiada ${ }^{27}$ dalej — ,zo-

2. Por. Denzinger-Schönmetzer: Enchiridion symbolorum, $\mathrm{nr} 312$.

27 Por. dz. cyt., nr 3020. 
stała przekazana Oblubienicy Chrystusa jako boski depozyt w tym celu, by była wiernie strzeżona i nieomylnie wyjaśniana, fi d e li t e r c u s t odienda et infallibiliter declaranda".

Misję nienaruszonego przechowywania nauki objawionej wypełnia Kościół w tych wszystkich dekretach doktrynalnych, których właściwym przedmiotem i celem nie jest ustalenie, jaka jest treść nauki objawionej, co jest prawdą a co fałszem, ale wskazanie, jaka nauka jest bezpieczna dla czystości wiary a jaka jest dla niej niebezpieczna. Niebezpieczną dla wiary jest ta nauka, co do której istnieje duże prawdopodobieństwo, że poważny odłam teologów i nieteologów wyciągnie z niej wnioski sprzeczne z objawieniem. Czyli mogą być takie sytuacje historyczne, że - z powodu braku odpowiedniego przygotowania i przemyślenia - nauka logicznie niesprzeczna czyli treściowo bezpieczna dla czystości wiary może być okazją do wyciągania z niej wniosków sprzecznych z objawieniem, stając się przez to niebezpieczną dla wiary. Historia Kościoła dostarcza przykładów na to, jak twierdzenia uznane na początku za niebezpieczne dla wiary stały się z biegiem lat bezpieczne i przestały być napiętnowane przez Kościół. Tak było nie tylko $\mathrm{z}$ orzeczeniami Komisji Biblijnej np. w sprawie c om ma J o a nn e u m ale nawet ze stanowiskiem Kościoła wobec poligenizmu, zakazanego encykliką $\mathrm{Humani}$ generis z r. $1950{ }^{28}$, obecnie zaś dozwolonego.

Do grupy orzeczeń zajmujących się właściwie tylko bezpieczeństwem wiary należą wszystkie dekrety kongregacyj rzymskich: dawnego św. Officjum, obecnej Kongregacji dla Spraw Wiary, Komisji Biblijnej, Penitencjarii i in. Stolica Apostolska wyraźnie tak określiła ich właściwe zadanie ${ }^{29}$. Np. kanon 247 Kodeksu prawa kanonicznego mówi o św. Officjum, że „chroni naukę wiary i obyczajów, tu ta t u r doctrinam fidei et morum". Stanowisko encykliki Humani generis wobec poligenizmu dowodzi, że nawet niektóre dekrety papieży mają na oku wyłącznie bezpieczeństwo wiary: o poligenizmie bowiem nie pisał Pius XII, że jest sprzeczny $\mathrm{z}$ objawieniem, ale tylko, iż nie widać, jak go można $z$ objawieniem pogodzić; nie orzekł, że jest b̉ędny, ale tylko - że nie wolno go katolikowi podtrzymywać.

Jest jasne, że wszystkie dekrety doktrynalne, których właściwym celem jest tylko zabezpieczenie czystości wiary, są z natury tymczasowe; dopuszczają zmianę stanowiska. Pod względem e pis temologicznym nie są pewne, ani naukowo ani tym mniej ponadnaukowo; mogą być uznane jedynie za prawdopodobne.

$28 \mathrm{Dz}$, cyt., $\mathrm{nr} 3897$.

29 Obszerniejsze studium na ten temat znajdzie czytelnik w mojej Metodologii teologii dogmatycznej, nr 407-420. 
Do misji wyjaśniania nauki objawionej odnosi się dogmat soboru watykańskiego I o nieomylności papieskiej, który orzeka, że Biskup Rzymski, gdy przemawia ex $\mathrm{c}$ a thedra, posiada w definiowaniu nauki wiary i obyczajów ,taką samą nieomylność, — w jaką w definiowaniu nauki wiary i obyczajów - z woli Boskiego Odkupiciela wyposażony został Jego Kościół" ${ }^{30}$ Dogmat odnosi się więc tylko do nieomylnych definicji; ale nie jest ani całą nauką I soboru watykańskiego, ani całą nauką Kościoła. Bo konstytucja soborowa D e i F i li u s, nie czyniąc żadnej różnicy między Kościołem a papieżem uczy, że jego misją jest nieomylnie wyjaśniać naukę objawioną, infallibiliter d e c l a r a nda ${ }^{31}$. Przez ,nieomylność”, infallibilitas, rozumie bezbłędność; a „wyjaśnianie”, d e claratio, posiada znacznie szerszy zakres niż „definiowanie": obejmuje zarówno nieomylne definicje jak i orzeczenia nie będące definicjami dogmatycznymi. Uczy więc, że wyjaśnianie nauki objawionej dokonywane przez Kościół posiada przywilej bezbłędności.

Kościół zaś był zawsze przekonany, że wyjaśnianie nauki objawionej dokonane przez niego jest bezbłędne, bez względu na to, czy dokonane zostało drogą nieomylnej definicji dogmatycznej czy w orzeczeniach, które nie mają jej znamion; bez względu na to czy zostało dokonane przez Kościół nauczający, zgromadzony na synodach lub soborach, czy indywidualnie przez papieża, działającego jako zwierzchnik całego Kościoła i w imieniu całego Kościoła. Wymownym wyrazem tej wiary Kościoła jest tradycyjny sposób, w jaki przystępuje do rozwiązywania trudności doktrynalnych: rozpoczyna od pytania, czy w przeszłości Kościół już nie odpowiedział na takie samo lub podobne pytanie. Jeśli taka odpowiedź już została dana, albo do niej nawiązuje albo ją wprost włącza do swych orzeczeń. Aby zaznaczyć tę ciągłość i niezmienność nauczania, sobór watykański II - na przykład - zaopatrzył wszystkie swoje konstytucje, dekrety i oświadczenia w odnośniki do wcześniejszych wypowiedzi papieży i soborów. Sobór trydencki wyraził swą nieomylną naukę o grzechu pierworodnym $w$ słowach II synodu z Orange ${ }^{32}$ oraz synodu kartagińskiego z r. $418^{33}$, mimo że doktrynalne postanowienia synodów partykularnych nie są z natury definicjami dogmatycznymi. Takie postępowanie jest możliwe do zrozumienia i wytłumaczenia, jeśli się przyjmie, że nie ma żadnego prawdopodobieństwa. by Kościółkiedyś pomyliłsię w wyjánianiu nauki objawionej, nawet wtedy, gdy dokonane w przeszło-

30 Denzinger-Schönmetzer, dz. cyt., nr 3074.

31 Tamże, nr 3020.

32 Tamże, $\mathrm{nr} 1512$ oraz $372 ; 1511$ oraz 371.

33 Tamże, nr 1513 oraz 223. 
ści wyjaśnienie było pozbawione cech nieomylnej definicji dogmatycznej. Prawdopodobieństwo błędu jest tym samym co możliwość błędu. Wobec tego ten sam wniosek może być równoważnie wyrażony także w brzmieniu: Możliwość błędu jest wykluczona nawet $\mathrm{w}$ tych orzeczeniach doktrynalnych Kościoła, które nie posiadają znamion definicji dogmatycznych, a są wyjaśnieniem treści objawienia.

B e z błędność wszystkich doktrynalnych orzeczeń Kościola, których właściwym celem jest wyjaśnienie treści nauki objawionej, jest koniecznym następstwem nieprzerwanejopieki Ducha św. nad Kościołem nauczającym. Tylko opieka człowieka nad drugim człowiekiem może być mniejsza lub czujniejsza; może być bardziej lub mniej skuteczna, a to dlatego, że siły człowieka są ograniczone. Opieka nieskończenie doskonałego i wszechmocnego Ducha św. musi być zawsze doskonała i wystarczająca do tego celu, dla którego została zapewniona. Ponieważ obiecana została Kościołowi dla zabezpieczenia go w objawionej prawdzie, Kościół musi być w wyjaśnianiu tej prawdy na zawsze zabezpieczony przed błędem.

Po tych rozważaniach można przystąpić do ujęcia w ścisłe twierdzenia nauki Kościoła o bezbłędności w wyjaśnianiu objawienia, a potem do próby teologicznej interpretacji całości danych objawienia $\mathrm{w}$ tej sprawie.

Nauka Kościoła wyraża się w dwu twierdzeniach: 1) Je żeli K ościół albo synodalnie albo indywidualnie przez papieża, jakozwierzchnikac ałegoKościoła, określa, jaka jest treść nauki objawionej, przedstawione przez niego, jej wyjaśnienie jest zawsze wolne od błędu. i prawdziwe.

2) Epistemologiczna wartość czyli pewność kaźdego wyjaśnienia nauki objawionej dokonanego przez Kościól, albo synodalnie albo indywidualnie przez papieża, wyraża się modalnym sądem apodyktycznym: jest bezwzględnie niemożliwe, by takie wyjaśnienie było błędne; względnie w postaci twierdzącej: każde takie wyjaśnienie nauki objawionej jest z konieczności prawdziwe.

Należy pamiętać o tym, że obydwa twierdzenia mówią o tych wszystkich wyjaśnieniach nauki objawionej, które nie osiągnęły stopnia definicji dogmatycznej, a potocznie - lecz nieściśle - bywają nazywane orzeczeniami omylnie pewnymi. W świetle nauki Kościoła ich ponadnaukowa pewność wysoko wyrasta ponad prawdopodobieństwo i o s i ąga najwyżsy stopień pewności, t.zn. pewność zdá́. 
a podyktycznych, ponad którą nie ma już wyższej jeszcze pewności.

Ponieważ pod względem swej treści są zawsze prawdziwe, nie mogą być treściowo zmienione i zastąpione inną treścią. Każde odstępstwo od ich treści byłoby odstępstwem od prawdy i popadnięciem w błąd. Dopuszczają jedynie możliwość ulepszeń w szacie pojęciowo słownej, pod warunkiem, że nowa szata słowna i pojęciowa zachowa to samo znaczenie.

Żadne z wyjaśnień nauki objawionej dokonanych przez Kościół nie jest rozwiązaniem tymczasowym, przyjętym z braku lepszego i właściwego do czasu, kiedy będzie można znaleźć odpowiedź nie tylko lepszą, ale całkowicie właściwą i prawdziwą. Dzięki nieprzerwanej pomocy Ducha św. Kościół nie jest skazany na to, by żyć tymczasowymi i przybliżonymi rozwiązaniami.

Owszem, w niemożliwości odrzucenia raz przyjętego wyjaśnienia nauki objawionej i zastąpienia go treściowo nowym wyraża się dogłębna istota Kościoła. Gdyby kiedyś Kośció $ł$ dokonał takiej zmiany, popełniłby samobójstwo: musiałby bowiem odciąć się od nieprzerwanej jedności z Chrystusem i Duchem św. - Duchem prawdy - a przez to również od prawdy; w tej samej chwili zaś przestałby być Kościołem Chrystusowym! Bezbłędność i zasadnicza, treściowa niezmienność wszystkich orzeczeń Kościoła, wyjaśniających treść objawienia - również tych, które nazywa się potocznie omylnie pewnymi - nie jest więc sprawą marginesową, ale najbardziej istotną, w której chodzi o przetrwanie Kościoła Chrystusowego.

Teologiczna interpretacja całości danych objawienia i nauki Kościoła o bezbłędności wszystkich aktów wyjaśniania treści objawienia przez Kościół wymagałaby dłuższej rozprawy; tutaj zostaną poruszone tylko te rysy, które mogą wzmocnić odpowiedź na pytania postawione niniejszej rozprawie.

Otóż w świetle całości danych objawienia nie ma wystarczającej podstawy do rozróżniania między nieomylnie zdefiniowanymi, czyli dogmatycznymi wyjaśnieniami treści objawionej a wyjaśnieniami, które nie są zdefiniowane i obiegowo nazywają się omylnie pewne. W s zystkie wyjaśnienia treści objawienia przez Kościól, bez względu na to, czy są definicjami czy nie, są właściwie i w jednakowym stopniu nieomylnie pewne: albowiem wszystkie, bez różnicy i bez wyjątku, posiadają znamiona wymagane przez definicję nieomylności, infallibilitas.

Nieomylność - pisze kard. Charles Journet w swej pomnikowej monografii L'Église du Verbe Incarné ${ }^{34}$ - ,jest czymś więk-

34 Paris 1955, t. I, 432. 
szym niż prosta, faktyczna wolność od błędu; jest ona bezbłędnością na mocy prawa, albowiem Kościół może we wszelkich okolicznościach liczyć na szczególną pomoc Bożą.". Lecz na skutek obietnicy Chrystusa może zawsze liczyć na tę szczególną pomoc Bożą, ilekroć dokonuje wyjaśnienia nauki objawionej, bez względu na to, czy posługuje się formą dogmatycznej definicji czy nie. Zatem każde wyjaśnienie nauki objawionej dokonane przez Kościół jest bezbłędne na mocy prawa, czyli nieomylne; nie tylko faktycznie jest wolne od błędu, ale wyklucza wszelką możliwość błędu.

Różnica między definicjami dogmatycznymi a określeniami treści nauki objawionej, które nie są definicjami, nie polega na różnym rodzaju wolności od błędu, ale na różnej modalności: ilekroć mianowicie Kościół definiuje dogmatycznie jakieś twierdzenie, określa i nadaje mu przez to nową moda l ność; określa tę jego modalność, że jest istotnie przez Boga objawione, a przez to samo równocześnie nadaje mu tę modalność, że musi być uznawane aktem wiary boskiej i katolickiej. Dlatego na przykład Pius IX, ogłaszając dogmat Niepokalanego Poczęcia, ujął jego treśé w takie modalne ramy: „Wyjaśniamy, ogłaszamy i definiujemy, że nauka... (ta)... jest przez Boga objawiona i dlatego musi być przez wszystkich uznawana aktem mocnej i niezachwianej wiary" ${ }^{35}$.

W świetle tej szkicowo przedstawionej interpretacji teologicznej dwie sprawy nie ulegają wątpliwości. Pierwszą jest konieczność wypracowania nowej doskonalszej terminologii, która by zastąpiła nieścisły i wprowadzający w błąd podział dekretów doktrynalnych Kościoła na nieomylnie pewne i omylnie pewne ${ }^{36}$. Drugą zaś jest to, że pod względem swej wartości epistemologicznej wszystkie dokonane przez Kościół wyjaśnienia nauki objawionej są $\mathrm{w}$ swej treści jednakowo nieomylnie pewne.

\section{HISTORYCZNE FAKTY A NIEZMIENNOSĆ NAUKI KOSCIOEA}

Prowizoryczność i zarazem rzeczową możność zmiany norm etycznych $\mathrm{Humanae}$ vitae K. Rahner, w swym artykule cytowanym wyżej w punkcie 1 tej rozprawy a ogłoszonym w Więzi usiłuje uzasadnić rozumowaniem sprowadzającym się do następującego schematu: „Historia zna "wypadki" papieskich wypowiedzi nauczycielskich o wadze zbliżonej do omawianej encykliki, które nie tylko ,teoretycznie” podlegały możliwości zmiany, ale też po cichu lub jawnie i wyraźnie były rewi-

35 Denzinger-Schönmetzer, dz. cyt., $\mathrm{nr} 2803$.

36 Terminologia stosowana przez autora w jego Metodologii teologii dogmatycznej, wydanej w r. 1947, wymaga więc uściślenia. Autor zamierza poświęcić temu zagadnieniu osobne studium. 
dowane" 37 Wobec tego również normy etyczne encykliki $\mathrm{H} \mathrm{u} \mathrm{manae}$ vita e mogą być kiedyś zrewidowane i zmienione.

W tym rozumowaniu kryje się niejeden błąd log ic zny: Naprzód, powołuje się K. Rahner na przykłady zmian stanowiska wyrażonego $\mathrm{w}$ dekretach o wadze zbliżonej do encykliki $\mathrm{H} \mathrm{u}$ manae vitae. Trudno nie ulec zdziwieniu, jak teolog takiej sławy mógł nie zauważyć niewystarczalności podobnej argumentacji! Wszak waga zbliżona jest właściwie różna, nie ta sama. A możliwość zmiany Humanae vitae mogłyby jedynie dowodzić fakty zmian doktrynalnych dokonanych $\mathrm{w}$ stosunku do orzeczeń wyrażonych $\mathrm{w}$ dekretach posiadających taką samą wagę jak encyklika $\mathrm{Humanae}$ vitae.

Drugi, zasadniczy, błąd K. R ahnera leży $w$ tym, że nie odróżnia orzeczeń doktrynalnych, których właściwym celem i przedmiotem jest określenie treści nauki objawionej dla całego Kościoła, od dekretów Stolicy Apostolskiej, które takiego celu nie mają. Wszystkie zaś przez niego przytoczone fakty zmian stanowiska Kościoła należą do grupy orzeczeń, które mają na celu jedynie strzeżenie czystości wiary i ograniczają się do wskazania na to, co dla czystości wiary jest bezpieczne lub niebezpieczne; nie wyrokują zaś bynajmniej, jaka jest właściwa treść wiary. Encyklika $\mathrm{Humana}$ e vita e tymczasem ma za cel właściwy wskazanie, jaka jest treść objawionego prawa Bożego w sprawie regulacji urodzin i dlatego nie należy do tej grupy orzeczeń. Stąd, że przytoczone przez K. Rahnera dekrety dopuszczały zmianę stanowiska Kościoła, nie wolno więc wyprowadzać wniosku, że dopuszcza ją również $\mathrm{H} \mathrm{umanae} \mathrm{vita} \mathrm{e;} \mathrm{a} \mathrm{nie} \mathrm{wolno} \mathrm{dlatego,} \mathrm{że} \mathrm{Hum}$ a na e vita e jest dekretem innego rzędu.

I tak, wyjaśniono już wyżej, że źródłem prowizoryczności dekretów w sprawach biblistycznych jest to, że ich celem nie jest ustalenie treści wiary, ale jedynie jej zabezpieczenie. Papież Wigiliusz, podany na przykład historycznej zmienności doktrynalnej Kościoła, nie okazał chwiejności w wyjaśnianiu treści wiary, ale $\mathrm{w}$ ocenie działalności tria kefalia, tj. Teodora z Mopswestii, Todoreta z Cyru i Ibasa z Edessy, do których potępienia zmuszał go cesarz Justynian. Ich potępienie którego jednak w swym Judic a t u m nie zatwierdził - mogło oznaczać tylko tyle, że w połowie VI wieku ich nauki stały się niebezpieczne bezpośrednio dla pokoju religijnego, a pośrednio dla wiary.

Sprawa papieża Honoriusza I sprowadza się do następujących punktów: nie wydał on w sprawie monoteletyzmu żadnego błędnego w swej treści określenia nauki objawionej; został zaś później potępiony za to,

38 Por. LThK, $5\left({ }^{2} 1960\right) 474-475$. 
że usiłując wyeliminować z życia problem monoteletyzmu i odsunąć konieczność doktrynalnego wyjaśnienia - posłużył się w listach do Sergiusza konstantynopolitańskiego językiem dwuznacznym, który e r r oribus fomentum dedit, został wykorzystany przez heretyków ${ }^{38}$. A za sformułowania tez Lutra w bulli Exsurge Domine nie jest odpowiedzialny Leon X, lecz sam Luter, bo zostały one prawie że dosłownie przejęte $z$ jego własnych dzieł.

W ostatecznym rozrachunku należy powiedzie : ani K. Rahner nie potrafił wskazać faktu historycznego, by Kościólodstąpił od dokonanego przez siebie wyjaśnienia nauki objawionej, ani wogóle historia nie zna takiego faktu.

\section{BEZBEĘDNOŚC I NIEZMIENNOŚC NORM ETYCZNYCH H U M A N A VI T A E}

Jest rzeczą bezsporną, że drugi sobór watykański nie dokonał żadn€j nieomylnej definicji dogmatycznej. Gdyby tezy teologów stojących za listem episkopatu zachodnioniemieckiego $\mathrm{w}$ sprawie prowizoryczności norm $\mathrm{Humanae}$ vita e były prawdziwe, miałyby zastosowanie również w odniesieniu do nauki soboru, która należy do tej samej klasy orzeczeń nie będących definicjami. Czyż biskupi niemieccy i ich teologowie odważyliby się twierdzić, że nauki drugiego soboru watykańskiego są tylko prowizoryczne, prawdopodobne i przyjęte $\mathrm{z}$ braku lepszych rozwiązań?

Przeprowadzone wyżej rozwiązania prowadzą do innego wniosku: wszystko co drugi sobór watykański podaje jako treść objawienia jest synodalnym określeniem nauki objawionej dokonanym przez Kościół i dlatego jest bezbłędne, wyklucza możliwość zmiany swej treści, posiada najwyższą epistemologiczną pewność ponadnaukową, która wyraża się w modalnym sądzie apodyktycznym: jest z konieczności prawdziwe i wyklucza błąd. Żadną miarą nie może być uważane za tylko tymczasowe i tylko prawdopodobne rozwiązanie.

To samonależy powtórzyć w sprawie norm etycznych Humanae vitae. Wszak nie ulega najmniejszej wątpliwości, że właściwym celem Pawła VI było dać w tej encyklice wykład norm obowiązujących na podstawie naturalnego prawa Bożego, które jest częścią objawienia Bożego. Dowodzą tego zamiaru zarówno okoliczności ogłoszenia encykliki, jak i własne słowa Pawła VI.

Okoliczności powstania encykliki są powszechnie znane: domagano sią od Kościoła, by jeszcze raz przebadał swą naukę potępiającą wszystkie sztuczne środki regulacji urodzin, czy rzeczywiście jest ona wyrazem 
naturalnego prawa Bożego, a przez to również i objawienia Bożego. Zmiana dotychczasowego stanowiska Kościoła, której powszechnie oczekiwano, byłaby bowiem tylko wtedy możliwa, gdyby się okazało, że prawo naturalne, w którym Bóg objawia nam swą wolę - wbrew encyklice Casti connubii - dopuszcza stosowalność sztucznych środków regulacji urodzin. Otóż encyklika $\mathrm{Hu}$ man ae vita e odpowiada na to powszechne żądanie stwierdzeniem: pomimo wszystkich sprzeciwów, Kościół „nie poprzestaje głosić, z pokorną stanowczością, całego prawa moralnego, tak naturalnego jak ewangelicznego. Kościół nie był jego autorem; dlatego nie może być jego panem; jest tylko jego powiernikiem i tłumaczem; nie może nigdy twierdzić, że jest dozwolone to, co nie jest dozwolone $z$ powodu swej dogłębnej a niezmiennej opozycji wobec prawdziwego dobra człowieka" ${ }^{39}$. W przytoczonych słowach wyrażona jest równoważnie myśl, że już Pius XI w encyklice $\mathrm{Casti}$ connubii ustalił bezbłędnie treść prawa natury odnośnie regulacji urodzin, a Pawłowi VI pozostało jedynie podtrzymać ten bezbłędny wykład objawienia Bożego, wyrażonego $\mathrm{w}$ prawie natury.

Trzeba nawet powiedzieć, że określenia prawa natury $\mathrm{w}$ sprawie niedopuszczalności sztucznych środków regulacji urodzin dokonał Pius XI w tak mocnych słowach, że po ukazaniu się encykliki Casti connubii pytano, czy nie jest ono przypadkiem prawdziwą, nieomylną definicją ex c a thedra ${ }^{40}$.

Gdyby więc Paweł VI zmienił naukę ustaloną przez Piusa XI w C asti connubii, znaczyło by to, że faktycznie Kościół pomylił się w ustalaniu treści objawienia Bożego, czyli przestał być Kościołem Chrystusowym nieprzerwanie zjednoczonym z Chrystusem i Duchem św. oraz korzystającym z nieprzerwanej opieki Ducha św. ${ }^{41}$.

Wobec tego normy etyczne encykliki $\mathrm{Humane}$ vitae posiadają wszystkie wyłożone wyżej znamiona bezbłędnego wyjaśnienia objawienia przez Kościół: są bezbłędne i prawdziwe. Nie są prowizorycznym tylko rozwiązaniem, przyjętym z braku właściwego, ale oddają wiernie przedmiotowy stan rzeczy. Posiadają najwyższy stopień ponadnaukowej pewności teologicznej, albowiem ich epistemologiczna wartość musi być wyrażona w apodyktycznym sądzie modalnym: są z konieczności prawdziwe i z konieczności wykluczają błąd. A teologiczna interpretacja da-

$39 \mathrm{Nr} 18$.

40 ,Ecclesia catholica... altam per os Nostrum extollit vocem atque denuo promulgat: quemlibet matrimonii usum, in quo exercendo, actus, de industria hominum, naturali sua vitae procreandae vi destituatur, Dei et naturae legem infringere, et eos, qui tale quid commiserint, gravis noxae labe commaculari", Denzinger-Schönmetzer, dz. cyt., nr 3717.

41 Por. memorandum mniejszości w łonie Papieskiej Komisji dla Regulacji urodzin: Herder-Korrespondenz, 21 (1967) 420 nn. 
nych objawionych każe nawet powiedzieć, że wykluczają nie tylko błąd, ale nawet i wszelką możliwość błędu.

Oczekiwać na zmianę stanowiska Kościoła wyrażonego w normach etycznych encykliki $\mathrm{Casti}$ connubii i $\mathrm{Humanae}$ vita e może tylko ten, kto albo nie wierzy w nieprzerwaną opiekę Ducha św. nad Kościołem albo nie zdaje sobie w pełni sprawy z jej następstw dla działalności Kościoła. Odmówić posłuszeństwa tym normom nie może nigdy człowiek, który w tę nieprzerwaną opiekę wierzy, poważnie ją bierze i zdaje sobie sprawę z jej następstw.

Eklezjologia nie pozostawia na przyszłość innej perspektywy niż ta, która wyraża się w twierdzeniu: jak długo Kościół Chrystusowy na ziemi. pozostanie sobą, zawsze głosił będzie niedopuszczalność sztucznych metod regulacji urodzin. Kto głęboko i rozumnie wierzy w Kościół, ten nie może się co do tego łudzić.

\section{Z U S A M M E N F A S S U N G}

DIE THEOLOGISCHE GEWISSHEIT DER IN ENZYKLIKA „HUMANAE VITAE” ENTHALTENEN ETHISCHEN NORMEN

Am Anfang schildert der Verfasser die Bewertung der Enzyklika „Humanae vitae" durch den westdeutschen Episkopat sowie durch Karl Rahner und Bernhard Häring: sie hat nämlich in Polen einige Anhänger gefunden. Dann wird der Zweck dieser Abhandlung erklärt. Dieser ist: dreigrundlegende Fragen zur Würdigung der Enzyklika zu beantworten: a) Kann die Gewissheit der ethischen Normen der Enzyklika ausschliesslich und genügend mit den Masstäben wissenschaftlicher Argumente gemessen werden? b) Liegt ihre Gewissheit innerhalb der Grenzen der Wahrscheinlichkeit? c) Wenn sie sich jedoch über die Grenzen der Wahrscheinlichkeit erhebt, wie ist dann ihr Wesen?

Der 2. Absatz der Abhandlung hat die Grundlagen der Lösung zum Ziel. Sie liegen nicht im Bereich wissenschaftlich theologischer Ethik, sondern sind der Ekklesiologie zuständig: die Enzyklika ist nämlich ein Akt des kirchlichen Lehramtes. Der erste, wesentlich ekklesiologische Grund dieser Lösung ist die Unwanderbarkeit der Lehre Christii, folglich die der Offenbarung- womit die Existenz und Unveränderlichkeit der Dogmen, ihren Inhalt nach, verbunden ist. Den zweiten Grund bietet die kotholische Lehre, die sich in der Behauptung ausdrückt: Die Obhut des Hl. Geistes, der eigentliche Ursache der Unfehlbarkeit der Kirche ist, umfasst alle Akte des kirchlichen Lehramtes. Eine Beschränkung dieser Obhut auf die Definitionen ex cathedra stehe in Widerspruch mit der Verheissung Christi von der immerwährenden Gegenwart des H1. Geistes in der Kirche. Daraus wird theologisch gefolgert und zum dritten Lösungsprinzip erhoben, dass die Gewissheit, die dem Urteil des kirchlichen Lehramtes eigen ist, keinen zureichenden Grund, rationem sufficientem, in wissenschaflichen Argumenten findet, die es theologisch 
be gründen. Deshalb ist diese Gewissheit als grösser und volkommener einzuschätzen; sie ist eine $\ddot{u} b e r w i s s e n s c h a f t l i c h e$ Gewissheit.

Num wird die Antwort auf die erste der drei gestellten Fragen lauten: Die ethischen Normen der Enzyklika H.v. haben eine theologisch überwissenschaftliche Gewissheit. Diese Gewissheit ist eine Folge der Obhut des Hl. Geistes und hat deshalb einen grösseren Grad als die von der Wissenschaft angeführten Beweise. Die ethischen Normen der Enzyklika sind nämlich eine tatsächlich von Paul VI beabsichtigte Erklärung des eigentlichen Sinnes der Offenbarung und kamen wirklich unter der Obhut des Hl. Geistes zustande. Solange man die Obhut des Hl. Geistes ernst nimt, kann man nicht die überwissenschaftliche Gewissheit der ethischen Normen der Enzyklika verneinen.

Zwecks der genaueren Abgrenzung der theologisch überwissenschaftlicher Gewissheit von anderen Gewissheitsgattungen unterscheidet der Verfasser erstens zwischen der Gewissheit in psychologischer Sicht und der Gewissheit in epistemologischer Sicht. Bei der Würdigung der ethischen Normen der Enzyklika geht es um die Gewissheit in epistemologischer Sicht. Diese wird am besten in assertorischen oder apodiktischen Modalsätzen a usgedrückt; in den Naturwissenschaften geschieht es durch assertorische Modalsätze, während den mathematischen Wissenschaften apodiktische Modalsätze eigen sind. Man muss z.B. sagen: es ist sicher, dass Wasser bei $0^{\circ}$ Centigrad friert; es ist absolut unmöglich, dass im euklidischen Dreieck die Summe der inneren Ecken nicht $180^{\circ}$ betrage.

Zweitens unterscheidet der Autor zwei Richtungen, in denen das kirchliche Lehramt Ausdruck findet; nämlich das unversehrte Aufbewahren des depositum fidei und die Sinneserklärung der Offenbarung, explicatio fidei.

Das führt zum folgenden Ergebnis: es gibt zwei grundsätzlich verschiedene Klassen kirchlichen Lehrmassnahmen. Den Massnahmen, die nur depositum sichern, ohne seinen Sinn zu explizieren, kommt nur die epistemologische Wahrscheinlichkeit $\mathrm{zu}$, die in problematischen Modalsätzen ausgedrückt werden kann. Die Massnahmen dagegen, die den Sinn der Offenbarung explizieren, haben höchsten Grad epistemologischer Gewissheit, der in apodiktischen Modalsätzen ausgedrückt werden muss.

Seiner Hauptthese gibt der Verfasser folgenden Wortlaut: 1) Sooft die Kirche - entweder synodalisch oder durch den Papst, als ihr Oberhaupt - erklärt, welcher der eigentliche Sinn der Offenbarungslehresei, die von ihr gefällte Sinneserklärung ist immer fehlerlos und wahr.

2) Die epistemologische Gewissheit jeder Sinneserklärung der Offenbarungslehre, welche durch die Kirche - entwedersynodalisch oderdurch den Papstals ihr Oberhaupt vorgenommen wird muss in einem apodiktischen Modalsatz ausgedrückt werden: nämlich, es ist absolut unmöglich, das solche Sinneserklärung falsch sei; order — in affirmativer Form - jede solche Sinneserklärung ist notwendigerweise wahr.

Diese ekklesiologische Haupthese hat für sich zwei zwingende Gründe: a) das Vorgehen des kirchlichen Lehramtes in der Geschichte; b) die immerwährende Obhut des Hl. Geistes, mit der ein Fehler in der Sinneserklärung der Offenbarungslehre unvereinbar ist. Und dieser höchste Grad der epistemologischen Gewissheit kommt auch den Sinneserklärungen, die von dem ordentli- 
chen Lehramt stammen und keine Definitionen ex cathedra sind. Wenn ein Satz unfehlbar, ex cathedra definiert wird, seine epistemologische Gewissheit wird dadurch nicht gesteigert; nur wird ihm eine neue Modalität verliehen, die den Satzungen des ordentlichen Lehramtes nicht zukommt: er wird als wesentlich geoffenbart und als Gegenstand des Glaubens erklärt. Daraus folgt, dass keine, von der Kirche einmal getroffene Sinneserklärung der Offenbarungslehre in der Zukunft ihrem Inhalt nach weder verwerfen noch geändert werden kann; keine von ihnen ist, ihrem Inhalt nach, provisorisch.

Die Beweisführungen $\mathrm{K}$. Rahners sind darum nicht überzeugend, weil in ihnen zwei logische Fehler begangen werden: erstens unterscheidet er nicht zwischen den Lehramtsakten, die nur tutandam doctrinam bezwecken, und denen, die den Sinn der Offenbarungslehre explizieren; nur die ersteren - wie es erwiesen wurde - sind prowisorisch und wahrscheinlich. Alle geschichtliche Tatsachen, die er zitiert, gehören dieser ersteren Klasse. Zweitens, entscheidene Folgerungen werden von ihm auf entfernte und lose Analogien gestüzt.

Nun ist es klar - sowohl aus dem Wortlaut wie aus der Vorgeschichte der Enzyklika - dass Paul VI für die ganze Kirche und als ihr Oberhaupt den eigentlichen Sinn des Naturrechts und somit der Offenbarung Gottes durch die ethischen Normen der Enzyklika H.v. zu erklären beabsichtigte. Darum sind die ethischen Normen der Enzyklika weder provisorisch noch bloss wahrscheinlich: sie haben den höchsten Grad der epistemologischen Gewissheit; sie schliessen jeden Fehler und jede Möglichkeit einer Änderung ihres Inhalts aus. 